\title{
Chemical Characteristics of Selected Grass Species from Polish Meadows and Their Potential Utilization for Energy Generation Purposes
}

\author{
Bogusława Waliszewska ${ }^{1, *}$, Mieczysław Grzelak ${ }^{2}$, Eliza Gaweł ${ }^{3}{ }^{10}$, Agnieszka Spek-Dźwigała ${ }^{1}$, \\ Agnieszka Sieradzka ${ }^{1}$ and Wojciech Czekała ${ }^{4}$ \\ 1 Department of Chemical Wood Technology, Poznan University of Life Sciences, Wojska Polskiego 38/42, \\ 60-637 Poznań, Poland; agnieszka.spek-dzwigala@up.poznan.pl (A.S.-D.); \\ agnieszka.sieradzka@up.poznan.pl (A.S.) \\ 2 Department of Grassland and Natural Landscape Sciences, Poznań University of Life Sciences, Dojazd 11, \\ 60-632 Poznan, Poland; mieczyslaw.grzelak@up.poznan.pl \\ 3 Department of Forage Crop Production, Institute of Soil Science and Plant \\ Cultivation-State Research Institute, Czartoryskich 8, 24-100 Puławy, Poland; eliza.gawel@iung.pulawy.pl \\ 4 Department of Biosystems Engineering, Poznań University of Life Sciences, Wojska Polskiego 50, \\ 60-627 Poznan, Poland; wojciech.czekala@up.poznan.pl \\ * Correspondence: boguslawa.waliszewska@up.poznan.pl
}

check for updates

Citation: Waliszewska, B.; Grzelak, M.; Gaweł, E.; Spek-Dźwigała, A.; Sieradzka, A.; Czekała, W. Chemical Characteristics of Selected Grass Species from Polish Meadows and Their Potential Utilization for Energy Generation Purposes. Energies 2021, 14, 1669. https://doi.org/10.3390/ en14061669

Academic Editor: Wei Qiao

Received: 14 January 2021

Accepted: 14 March 2021

Published: 17 March 2021

Publisher's Note: MDPI stays neutral with regard to jurisdictional claims in published maps and institutional affiliations.

Copyright: (c) 2021 by the authors. Licensee MDPI, Basel, Switzerland. This article is an open access article distributed under the terms and conditions of the Creative Commons Attribution (CC BY) license (https:// creativecommons.org/licenses/by/ $4.0 /)$.

\begin{abstract}
Analyses were conducted on 10 grass species from permanent grasslands in the Noteć Leniwa and Noteć Bystra valley. Their chemical composition was assayed, and their heat of combustion and heating value were determined. The cellulose content ranged from $33.38 \%$ to $38.68 \%$, while the content of lignin ranged from $15.42 \%$ to $21.99 \%$, and that of hemicellulose from $30.27 \%$ to $34.31 \%$. The heating value of grasses was comparable to that of wood from 2- to 3-year-old willows and other fast-growing energy crops. However, the calorific value of naturally dried grasses may be slightly lower. The quantities of minerals in these grasses, exceeding those in wood, did not result in a lowering of their heat of combustion. The analyses clearly showed that the investigated grass species may be successfully used for energy generation purposes.
\end{abstract}

Keywords: chemical composition of grass; cellulose; lignin; ash; calorific value

\section{Introduction}

In view of the current search for energy materials providing an alternative to fossil fuels, plant biomass from annual grass species appears to be a promising source. According to the European Environment Agency [1], plant biomass for energy purposes shows the greatest potential among renewable energy sources in Poland. This is connected with its availability, its cost-effectiveness as a fuel, and the relatively low costs of the combustion system. Additionally, the rational utilization of renewable energy sources is an essential element of a sustainable economy. When conditions were adopted in 2020 to ensure a $15 \%$ share of renewable sources in energy generation, it was assumed that the increased contribution of renewable sources would be based on the utilization of plant biomass. At present, wood biomass (chips, pellets, briquettes and sawdust) is the plant biomass material used most commonly in Poland [2]. In turn, in agricultural biogas plants, frequently used substrates include by-products of agricultural production, i.e., plant waste biomass, as well as straw or sugar beet pulp [3,4]. In the case of the so-called dedicated energy crops (DEC) for biogas production, such as maize grown for silage [5], a potential conflict may arise between food production and cultivation for feedstocks [6]. An alternative in such cases may be provided by the cultivation of dedicated energy crops on poorer, frequently degraded soils $[7,8]$, or barren lands.

Advantages of plant biomass over fossil fuels include the low contents of sulfur and nitrogen as well as its approximately fourfold greater oxygen content. Additionally, the 
combustion of straw instead of wood produces lower emissions of polycyclic aromatic hydrocarbons (PAHs), such as naphthalene, phenanthrene, fluoranthene and pyrene [9].

It is also noteworthy that plant material from permanent grassland may be used as a biogas plant substrate and (particularly in the case of plants with high contents of lignocellulose compounds) as a structural material in the composting process [10,11]. The primary factor affecting the proper course of this process is the availability of oxygen [12]. Due to their porous structure, straw and grass provide adequate oxygen during composting [13].

Plant biomass with increased contents of lignocellulose compounds (i.e., grasses and straw) may also be used as a quality substrate for agricultural biogas plants [14]. Due to their lower water content, dried grasses or straw (e.g., maize straw, also called corn stover) may provide higher biogas yields than maize silage, the most popular substrate in European biogas plants [4]. An important aspect of the use of biomass of plant origin is the production of various types of chemical substances. This is an important process for the substitution of petrochemical products. Substances such as furfural, alcohols, levulinic acid, 5-hydroxymethylfurfural, lactic acid, succinic acid and phenols are valuable substrates in the chemical industry and can successfully replace petrochemical products [15].

Permanent grasslands in Poland cover 3.1 million ha, which accounts for $21.4 \%$ of the utilized agricultural area and $10.5 \%$ of the country's total area [16]. It includes both natural and semi-natural grassland (approx. 50\% of the total area) as well as anthropogenic grassland, i.e., grassland subjected to periodical renovation using seeds of meadow plants for the undersowing and sowing of new meadows and pastures, treated as valuable pastures (approx. 50\% of the total area). The basic function of grasslands in terms of their utilization is to provide feed for graminivorous animals. On organic farms, the biomass formed in the process of photosynthesis is used as a valuable energy material to produce pellets and briquettes. Among native grass species, those characterized by particularly high yields are recommended for the production of solid biomass. These species include reed canary grass (Phalaris arundinacea), common reed (Phragmites australis), awnless brome (Bromus inermis), cock's foot (Dactylis glomerata) and false oat-grass (Arrhenatherum elatius). Moreover, there has been increasing interest recently in introduced grass species, mainly from the genus Miscanthus, such as giant miscanthus (Miscanthus $x$ giganteus), Amur silvergrass (Miscanthus sacchariflorus) and maiden silvergrass (Miscanthus sinnensis), as well as other C4 grasses, such as prairie cordgrass (Spartina pectinata) and switchgrass (Panicum virgatum) [17]. An advantageous aspect of the utilization of such biomass for energy generation is the neutral effect of their combustion on greenhouse gas emissions to the atmosphere. The zero-carbon balance of plant biomass is commonly known and acknowledged [18]. The suitability of solid biofuels for energy generation is determined by many factors, including the heat of combustion parameters and the contents of cellulose, lignin and ash [19]. The literature sources present information on the chemical composition of native tree and shrub species as well as many introduced plants offering high biomass yields $[20,21]$. However, practically no data are available on the chemical composition and heating value of common grass species found in Polish meadows.

A characteristic property of plant biomass is the heterogeneity of its anatomical structure and differences in the chemical composition even within the same species. These depend on many factors, including location, plant age or even the part of the plant. These factors affect the potential industrial uses of the raw material. Thus, for the rational utilization of plant raw materials, it is essential to know the contents and quality of their individual components [22,23].

The utilization of grasses harvested from grassland for energy generation purposes is in line with the assumptions of the EU climate and energy policy aimed at reducing greenhouse gas emissions by 2030 and achieving the long-term low-emission strategy by 2050, which is an important element for the reduction in greenhouse gas emissions [14].

The aim of this study was to analyze the chemical composition of the aboveground parts of plants and to determine the heat of combustion and heating value of selected grass species, with a view to their utilization for energy generation purposes. Based on this 
comprehensive analysis of biomass composition, an indication will be made of the possible end uses of each species.

Hypothesis 1. The hypothesis of the present work is that the studied grass species are suitable for bioenergy conversion.

\section{Materials and Methods}

Ten grass species commonly found on grassland in Poland were selected for this study. The species are reed canary grass (Phalaris arundinacea L.), wood small-reed (Calamagrostis epigejos L. Roth), common reed (Phragmites australis Cav.), couch grass (Elymus repens L. Gould.), downy brome (Bromus tectorum L.), false oat-grass (Arrhenatherum elatius (L.) P. Beauv. ex J. Presl \& C. Presl), common bent (Agrostis capillaris L.), sweet vernal grass (Anthoxanthum odoratum L.), cock's foot (Dactylis glomerata L.) and velvet grass (Holcus lanatus L.). A composite material in the mature form (leaves and culms together with inflorescences) was harvested in the Noteć Leniwa and Noteć Bystra valley (Wielkopolskie province, Białośliwie and Trzcianka communes) and in Rakowo (Lubuskie province, Skwierzyna commune). They are semi-natural grassland ecosystems, and farmers, when realizing the Environmental Management Scheme, run their farms in an environmentally friendly manner. The harvested biomass exhibits an average fodder value, but it is a valuable raw material for the production of pellet and briquettes used for energy generation. The share of certain dominant species in the plant community reaches up to $80 \%$ or even $100 \%$, e.g., in the case of reeds or canary grass. The study area covered 148 ha.

The communities from which the research material was collected are semi-natural grassy ecosystems subject to extensive use. The grasses were harvested in the initial stage of heading, from the end of May to mid-August (2020), depending on the phase of growth and development of a given species. About $1 \mathrm{~kg}$ of material was collected from a homogeneous $10 \times 10 \mathrm{~m}$ surface area. The harvested material was processed in an air-conditioned facility until constant moisture content was attained. Next, it was cut manually and ground in an SM 200 laboratory mill (Retsch). For chemical analyses, the $0.1-0.4 \mathrm{~mm}$ analytical fraction was isolated, and for heat of combustion, the $<0.1 \mathrm{~mm}$ fraction was used in the analyses.

The chemical composition of the investigated grasses was assayed using standard methods applied in analyses of plant biomass:

- Extractive contents were determined using 96\% ethanol according to Soxhlet (TAPPI-T $204 \mathrm{~cm}-07)$ [24];

- Cellulose content was determined by the Seifert method with a mixture of acetylacetone and dioxane at an acid $\mathrm{pH}[25]$;

- Lignin content was determined by the Tappi method using $72 \%$ sulfuric acid (TAPPI-T 222 om-06) [26];

- Holocellulose content was assayed using sodium chlorite (TAPPI-T 9 wd-75) [27];

- The theoretical content of hemicellulose was calculated mathematically as a difference between holocellulose and cellulose contents;

- Contents of ash were determined according to the DIN 51731 standards [28].

All results were calculated in relation to the raw material's dry mass and given as a mean from three measurements. Moisture content was determined using the oven-dry method. This consists in weighing approx. $2 \mathrm{~g}$ of the sample and drying in a dryer at a temperature of $103 \pm 2 \mathrm{oC}$ until constant mass. The difference between weighed values did not exceed $0.01 \%$.

The heat of combustion was determined according to the PN-81/G-04513 standard in a ZKL-4 calorimeter, designed for determination of the heat of combustion $\left(Q_{s}^{a}\right)$ of solid fuels. A $1 \mathrm{~g}$ analytical sample of raw material was completely combusted under oxygen atmosphere and $3 \mathrm{MPa}$ pressure. 
The values were calculated according to the formula:

$$
\mathrm{Q}_{\mathrm{s}}^{\mathrm{a}}=\frac{\mathrm{C}\left(\mathrm{D}_{\mathrm{t}}-\mathrm{k}\right)-\mathrm{c}}{\mathrm{m}} \quad(\mathrm{kJ} / \mathrm{kg})
$$

where

$\mathrm{C}$ is the heat capacity of the calorimeter, $12,783.69\left(\mathrm{~J} /{ }^{\circ} \mathrm{C}\right)$;

$\mathrm{D}_{\mathrm{t}}$ is the temperature rise in the main period $\left({ }^{\circ} \mathrm{C}\right)$;

$\mathrm{k}$ is a correction for heat exchange with the surroundings $\left({ }^{\circ} \mathrm{C}\right)$;

$\mathrm{c}$ is the sum of corrections for additional thermal effects (J);

$\mathrm{m}$ is the mass of the fuel sample $(\mathrm{g})$.

To provide a more comprehensive characterization of the analyzed raw material, the heating value of the investigated grasses was also calculated, as the heat of combustion reduced by the heat of vaporization of water released during combustion.

The values were calculated according to the following formula:

$$
\mathrm{Q}_{\mathrm{i}}^{\mathrm{a}}=\mathrm{Q}_{\mathrm{s}}^{\mathrm{a}}-24.42\left(\mathrm{~W}^{\mathrm{a}}-8.94 \mathrm{H}^{\mathrm{a}}\right)(\mathrm{kJ} / \mathrm{kg})
$$

where

$\mathrm{Q}_{\mathrm{s}}^{\mathrm{a}}$ is the average gross calorific value of solid fuel in the analytical state $(\mathrm{J} / \mathrm{g})$;

The heat of vaporization of water at $25{ }^{\circ} \mathrm{C}$ is 24.42 , corresponding to $1 \%$ of water in the fuel $(\mathrm{J} / \mathrm{g})$;

$\mathrm{W}^{\mathrm{a}}$ is the moisture content in the analytical sample of fuel (\%);

The analytical factor for the conversion of hydrogen content to water content is 8.94;

$\mathrm{H}^{\mathrm{a}}$ is the hydrogen content in the analytical sample of fuel, according to the PN-EN ISO 16948: 2015-07 [29].

Statistical Analysis

The statistical analysis of the chemical composition of the grasses was performed using STATISTICA 10 (StatSoft LTD, Cracow, Poland), including analysis of variance (ANOVA) followed by a post hoc Tukey's honestly significant difference (HSD) test. Identical letters in columns represent no differences at a significance level of $p=0.05$.

\section{Results}

Analysis of the data given in Table 1 indicates the differences in the amounts of structural components in the investigated grass species. The content of the basic component, cellulose, ranged from $33.38 \%$ in the case of Agropyron repens to $38.68 \%$ in Phalaris arundinacea. Five of the studied species had very similar levels of cellulose, within the range $35.05-35.60 \%$. These were Calamagrostis epigejos, Phragmites australis, Bromus inermis, Arrhenatherum elatius and Anthoxanthum odoratum. A high cellulose content of over 38\% was recorded in Agrostis capillaris, and a slightly lower level (37.71\%) in Dacylis glomerata. In Holcus lanatus, $36.43 \%$ cellulose was recorded.

The variation in lignin content in the investigated grass species was over $6.5 \%$, which was greater than in the case of cellulose. The highest level of lignin, $21.99 \%$, was found in Phragmites australis, and the lowest, $15.42 \%$, in Phalaris arundinacea, in which the greatest cellulose content was recorded (Table 1). Over $20 \%$ lignin was also found in two other species, Calamagrostis epigejos and Agrostis capillaris. Similar lignin contents were observed in Arrhenatherum elatius, Anthoxanthum odoratum and Holcus lanatus $(17.54 \%, 17.68 \%$ and $17.18 \%$, respectively). Statistical analysis confirms these similarities. 
Table 1. The chemical composition of investigated grass species.

\begin{tabular}{|c|c|c|c|c|c|}
\hline \multirow[t]{2}{*}{ Grass Species } & \multicolumn{5}{|c|}{$\begin{array}{c}\text { Contents [\%] } \\
\text { DM }\end{array}$} \\
\hline & Extractives & Cellulose & Lignin & Holocellulose & Hemicellulose \\
\hline Phalaris arundinacea $\mathrm{L}$. & $12.77 \pm 0.22^{c}$ & $38.68 \pm 0.01^{\mathrm{d}}$ & $15.42 \pm 0.01^{a}$ & $70.39 \pm 0.89^{b}$ & $31.71 \pm 1.46^{\mathrm{abcd}}$ \\
\hline $\begin{array}{c}\text { Phragmites australis (Cav.) } \\
\text { Trin. ex Steud }\end{array}$ & $14.46 \pm 0.06^{\mathrm{d}}$ & $35.05 \pm 0.14^{b}$ & $21.99 \pm 0.15^{f}$ & $65.32 \pm 0.23^{a}$ & $30.27 \pm 0.15^{\mathrm{a}}$ \\
\hline Dacylis glomerata L. & $10.59 \pm 0.15^{a b}$ & $37.71 \pm 0.41^{\mathrm{cd}}$ & $19.33 \pm 0.05^{\mathrm{d}}$ & $69.19 \pm 1.29^{b}$ & $31.48 \pm 1.13^{\mathrm{abc}}$ \\
\hline Arrhenatherum elatius & $15.00 \pm 0.17^{\mathrm{d}}$ & $35.46 \pm 0.20^{b}$ & $17.54 \pm 0.15^{\mathrm{c}}$ & $68.63 \pm 0.09^{b}$ & $33.17 \pm 0.25^{\text {cde }}$ \\
\hline Bromus inermis Leyss. & $18.26 \pm 0.05^{\mathrm{e}}$ & $35.6 \pm 0.51^{\mathrm{b}}$ & $16.5 \pm 0.60^{b}$ & $69.31 \pm 0.95^{b}$ & $33.71 \pm 1.15^{\mathrm{e}}$ \\
\hline Agrostis capillaris L. & $11.29 \pm 0.44^{b}$ & $38.29 \pm 0.18^{d}$ & $20.48 \pm 0.14^{\mathrm{e}}$ & $69.37 \pm 0.39^{b}$ & $31.08 \pm 0.39 \mathrm{ab}$ \\
\hline Calamagrostis epigejos L. (Roth) & $9.42 \pm 0.01^{\mathrm{a}}$ & $35.35 \pm 0.19^{b}$ & $20.96 \pm 0.09{ }^{\mathrm{e}}$ & $69.01 \pm 0.43^{b}$ & $33.66 \pm 0.9^{\mathrm{de}}$ \\
\hline Agropyron repens L. & $15.52 \pm 1.07^{\mathrm{d}}$ & $33.38 \pm 1.35^{\mathrm{a}}$ & $18.76 \pm 0.19^{d}$ & $64.22 \pm 0.52^{\mathrm{a}}$ & $30.84 \pm 0.84^{\mathrm{ab}}$ \\
\hline Anthoxanthum odoratum L. & $9.72 \pm 0.28^{a}$ & $35.18 \pm 0.28^{b}$ & $17.68 \pm 0.04^{\mathrm{c}}$ & $69.49 \pm 0.48^{b}$ & $34.31 \pm 0.20^{\mathrm{e}}$ \\
\hline Holcus lanatus L. & $13.07 \pm 0.17^{\mathrm{c}}$ & $36 ., 43 \pm 0.40^{\mathrm{c}}$ & $17.18 \pm 0.16^{c}$ & $69.00 \pm 0.55^{b}$ & $32.57 \pm 0.32$ bcde \\
\hline
\end{tabular}

Mean values $(\mathrm{n}=3) \pm$ standard deviations; identical superscripts $(\mathrm{a}-\mathrm{e})$ in a column denote no significant difference $(p<0.05)$ between mean values according to Tukey's HSD test (ANOVA).

A low content of this component (16.50\%) was recorded in Bromus inermis. Agropyron repens contained $18.76 \%$ lignin, and Dacylis glomerata $19.34 \%$.

Holocellulose content in the studied grass species was in the range $69.00-69.49 \%$ (Table 1) for the species Holcus lanatus, Calamagrostis epigejos, Dacylis glomerata, Bromus inermis, Agrostis capillaris and Holcus lanatus. Only Phalaris arundinacea contained over $70 \%$ holocellulose, while Agropyron repens had $64.22 \%$, and Phragmites australis $65.32 \%$.

The calculated contents of hemicellulose exhibited a slight variation. They ranged from $30.27 \%$ in common reed to $34.31 \%$ in Holcus lanatus (Table 1). Slightly over $33 \%$ hemicellulose was found in Arrhenatherum elatius, Calamagrostis epigejos and Bromus inermis. Low contents were recorded in Agropyron repens (30.84\%), Agrostis capillaris (31.08\%), Dacylis glomerata $(31.48 \%)$ and Phalaris arundinacea $(31.71 \%)$. Holcus lanatus contained $32.57 \%$ carbohydrates with a low degree of polymerization.

Among the assayed compounds, the greatest variation between grass species was observed in the contents of substances extracted with ethanol. The differences were almost as high as $100 \%$ (Table 1). The highest level of these compounds $(18.26 \%)$ was recorded in Bromus inermis, and the lowest in wood small-reed (9.42\%) and Anthoxanthum odoratum $(9.72 \%)$. Slightly higher contents of extractives were recorded in cock's foot $(10.59 \%)$ and common bent (11.29\%). Agropyron repens and Arrhenatherum elatius contained large amounts of extractives (15.52\% and $15.00 \%$, respectively). A slightly lower level of these substances, $14.46 \%$, was found in Phragmites australis. In Anthoxanthum odoratum and Phalaris arundinacea, comparable amounts of extractives were recorded $(13.07 \%$ and $12.77 \%$, respectively).

The plant material for analyses was stored (for about two weeks) in an air-conditioned facility, which resulted in very similar moisture contents for all samples, within a narrow range from $6.2 \%$ to $6.7 \%$ (Table 2). (In practice, the grasses are dried in the meadow and reach a humidity of about $15 \%$.) This was a low moisture content, which had no marked effect on the variation in heat of combustion. The hydrogen content in the tested grass samples is presented in Table 3. 
Table 2. Moisture content, heat of combustion and heating value of investigated grass species.

\begin{tabular}{cccc}
\hline Grass Species & Moisture Content (\%) & Heat of Combustion (MJ/kg) & Heating Value (MJ/kg) \\
\hline Phalaris arundinacea L. & $6.4 \pm 0.02$ & $18.757 \pm 0.031$ & $17.293 \pm 0.030$ \\
Phragmites australis (Cav.) & $6.7 \pm 0.09$ & $18.842 \pm 0.032$ & $17.386 \pm 0.031$ \\
Trin. ex Steud & $6.2 \pm 0.05$ & $17.598 \pm 0.019$ & $16.129 \pm 0.019$ \\
Dacylis glomerata L. & $6.7 \pm 0.05$ & $18.455 \pm 0.037$ & $16.989 \pm 0.036$ \\
Arrhenatherum elatius & $6.2 \pm 0.03$ & $18.707 \pm 0.010$ & $17.231 \pm 0.010$ \\
Bromus inermis Leyss. & $6.4 \pm 0.01$ & $17.527 \pm 0.001$ & $16.066 \pm 0.002$ \\
Agrostis capillaris L. & $6.4 \pm 0.01$ & $19.496 \pm 0.032$ & $18.037 \pm 0.032$ \\
Calamagrostis epigejos L. (Roth) & $6.6 \pm 0.05$ & $19.252 \pm 0.037$ & $17.793 \pm 0.036$ \\
Agropyron repens L. & $6.3 \pm 0.06$ & $17.912 \pm 0.038$ & $16.436 \pm 0.036$ \\
Anthoxanthum odoratum L. & $6.7 \pm 0.05$ & $17.502 \pm 0.039$ & $16.029 \pm 0.038$ \\
Holcus lanatus L. & &
\end{tabular}

Table 3. Hydrogen content in analytical samples.

\begin{tabular}{cccc}
\hline Grass Species & H (\%) DM & Grass Species & H [\%] DM \\
\hline Phalaris arundinacea L. & $6.17 \pm 0.04$ & Agrostis capillaris L. & $6.04 \pm 0.04$ \\
Phragmites australis (Cav.) & $5.83 \pm 0.08$ & Calamagrostis epigejos L. (Roth) & $6.08 \pm 0.09$ \\
Trin. ex Steud & $5.90 \pm 0.08$ & Agropyron repens L. & $6.07 \pm 0.03$ \\
Dacylis glomerata L. & $6.02 \pm 0.06$ & Anthoxanthum odoratum L. & $6.04 \pm 0.06$ \\
Arrhenatherum elatius & $6.03 \pm 0.02$ & Holcus lanatus L. & $5.99 \pm 0.04$ \\
Bromus inermis Leyss. & &
\end{tabular}

The contents of ash in the studied grass species are given in Figure 1. The levels of these compounds were relatively varied, ranging from $3.26 \%$ in the case of sweet vernal grass to $8.27 \%$ in false oat-grass. Large amounts of ash (7.00-7.21\%) were recorded in three more species: Agropyron repens, Phalaris arundinacea and Bromus inermis. Calamagrostis epigejos had a 5.04\% ash content. The ash contents in Phragmites australis, Holcus lanatus, Dacylis glomerata and Agrostis capillaris were comparable, in the range 5.98-6.58\%.

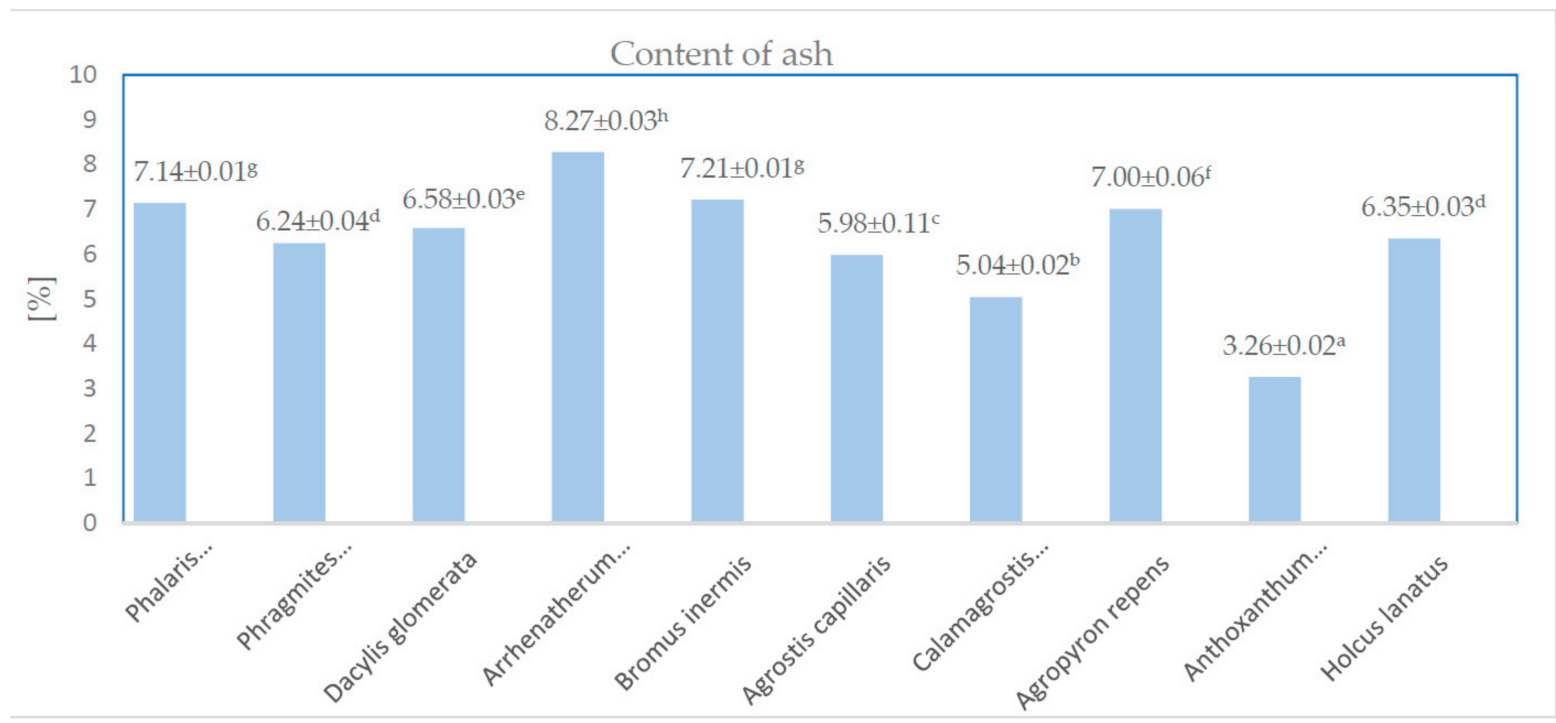

Figure 1. Content of ash. Mean values $(n=3) \pm$ standard deviations; identical superscripts $(a, b, c \ldots)$ denote no significant difference $(p<0.05)$ between mean values according to Tukey's HSD test (ANOVA).

Based on the heat of combustion, the studied grass species could be divided into three groups. The first group, with the highest values (over $19.000 \mathrm{MJ} / \mathrm{kg}$ ), consisted of Calamagrostis epigejos (19.496 MJ/kg) and Agropyron repens (19.252 MJ/kg) (Table 2). For the second 
group of grasses, the heat of combustion was in the range $18.455-18.842 \mathrm{MJ} / \mathrm{kg}$, while the third group had the lowest values, from 17.500 to slightly over $17.900 \mathrm{MJ} / \mathrm{kg}$. Low heats of combustion were recorded for Agrostis capillaris, Dacylis glomerata and Holcus lanatus.

The heating value of the investigated grass species, i.e., their heat of combustion reduced by the heat of water vaporization, followed a similar pattern (Table 2). Only Calamagrostis epigejos had a heating value over $18.000 \mathrm{MJ} / \mathrm{kg}$. Five species had heating values in the range $16.029-16.989 \mathrm{MJ} / \mathrm{kg}$. For the other species, slightly higher heating values were recorded, from 17.231 to $17.793 \mathrm{MJ} / \mathrm{kg}$.

\section{Discussion}

In Poland, the production of fodders using organic cultivation methods in the Natura 2000 area covers a rich mosaic of habitats associated with high levels of groundwaters. This has contributed to the maintenance of the highly natural character of habitats, and the plant communities developed under these conditions exhibit considerable potential for the production of biomass at a simultaneously high nature value. In the case of extensively managed areas, an excess of produced fodder is a valuable substrate for the production of fuel.

For the appropriate and optimal utilization of biomass, it is crucial to know the contents of its individual components [30]. Plant biomass used for energy generation purposes needs to meet specific requirements [31]. Its value is typically assessed based on the heat of combustion and heating value. However, information on the contents of its chemical components may also be a valuable indicator for the optimal utilization of this raw material.

The primary component of lignocellulose materials is cellulose, which due to its fibrous structure provides cells with mechanical strength. The amount of cellulose in plants varies greatly and depends on many factors, such as species, plant age and growth conditions, as well as the part of the plant [32-35]. Plant biomass of annual species contains approximately 20-40\% cellulose. The highest level of pure cellulose is found in cotton, in which it may be as high as $98 \%$, while ramie has a level of approx. $76 \%$, flax approx. $71 \%$ and straw approx. $40 \%$ [32]. Miscanthus is gaining in popularity as an engy crop providing high yields of biomass. Some varieties are cultivated even under difficult growth conditions (such as those in Siberia), giving satisfactory biomass yields [23]. In that study, cellulose contents in five Miscanthus plants aged from 1 to 5 years, determined by the Kürschner method, were reported to range from $42 \%$ to $54 \%$. This is a relatively high amount of cellulose in grasses harvested in a 1-year cycle. Doczekalska et al. [36], in a study on the chemical composition of three Miscanthus species (M. giganteus, M. sacchariflorus and $M$. sinensis) to be used for biochar, reported the content of cellulose to range from $44.12 \%$ to $45.12 \%$, while in switchgrass (Panicum virgatum), it was $40.30 \%$. This is approximately $10 \%$ higher than the cellulose content of the grass species investigated in this study. In turn, in grasses from the genus Carex, very similar contents of the main biomass component were reported in most cases, from 35\% to $40 \%$ [37]. Only Carex praecox was found to have a low level of cellulose (30.1\%), while in Carex riparia, it was as high as $46.2 \%$. The cellulose content of C. riparia was comparable to that of Miscanthus species, and almost $8 \%$ higher than that of reed canary grass, which contained $38.68 \%$ of these compounds. A low content of cellulose of approximately $31 \%$ in different grass species (Lolium perenne, Dactylis glomerata, Poa pratensis and Festuca pratensis) was reported by Dandikas et al. [22], who investigated the relationship between the chemical composition of plants and the yield of biogas. A similar amount of cellulose, ranging from $36 \%$ to $42 \%$, in Napier grass (Pennisetum purpureum) was recorded by Ansah et al. [38]. Among the fast-growing plants used for energy generation purposes, an important example is Salix viminalis, a species with a number of varieties and clones. The amount of cellulose in the wood of different clones (Corda, Tur, Turbo, Duotur, UWM 046) harvested in a 1-year cycle was 39-41\%, comparable to the contents of cellulose in reed canary grass $(38.68 \%)$ and common bent $(38.29 \%)$. 
Lignin is the second most abundant component of plant biomass. Its content in lignocellulose raw materials amounts to $16-32 \%$. It is a natural bonding component enhancing the stability of biomass, while its chemical structure gives it a high heating value. Among the investigated grasses, the greatest amount of lignin, almost $22 \%$, was recorded in common reed, which is comparable to the value for Miscanthus giganteus reported by Doczekalska et al. [36]. Those authors reported approx. 20\% lignin in Miscanthus sacchariflorus, $M$. sinensis and $P$. virgatum (switchgrass), comparable to the values for several grass species investigated in this study (wood small-reed, common bent and cock's foot). Similar lignin contents were found in grasses from the genus Carex-C. acutiformis (20.3\%) and C. paniculata (20.8\%) [37]. Many grasses, however, have lower lignin contents (approx. $15-17 \%$ ); in this study, these were reed canary grass, downy brome, false oat-grass, sweet vernal grass and velvet grass. Similar amounts of lignin were also recorded in C. flava and C. brizoides [37]. A considerable variation in lignin contents (from $15.7 \%$ to $28.1 \%$ ) in grasses from extensively managed meadows in the Wielkopolska region was reported by Murawski et al. [39]. Strongly lignified stems of energy crops, such as Salix viminalis or clones from the genus Salix (UWM 006 and UWM 043), showed slightly higher levels of lignin, close to $25 \%$ [40], while values reported for the clones Turbo and Duotur were $25.27 \%$ and $24.71 \%$, respectively [41]. (In Poland, Salix viminalis is a commonly cultivated species, and it is generally called energy crop willow. It is a fast-growing species, providing high yields within a short cycle and characterized by a high heating value.) A high lignin content, $24.8 \%$, in bamboo wood was recorded by Chen et al. [42]. A very low amount of lignin, from $8.9 \%$ to $13.8 \%$, in Napier grass was reported by Ansah et al. [38]. According to the literature data, woody plant parts contain slightly more lignin than grasses harvested in a 1-year cycle. However, differences in the contents of this component are not large, and their amounts are sometimes comparable. The amount of lignin in the investigated grasses in this study was characteristic for this type of plants harvested in a 1-year cycle. The low lignin content in Phalaris arundinacea did not reduce the heat of combustion of that grass species.

The total content of polysaccharide substances (holocellulose) in the studied grasses $(64.22-70.39 \%)$ was slightly lower than that of hardwood (70-78\%) [32]. This is connected with the relatively high level of extractives in grasses (9-18\%). However, it did not result in a considerable reduction in the heat of combustion in the investigated grasses. A low content of holocellulose, amounting to $52.4-68.1 \%$, in grasses from extensively managed meadows was reported by Murawski et al. [39]. Compared to the wood of an energy crop in the genus Salix (clones UWM 006 and UWM 043), this is a much lower level of holocellulose, since as stated by Krzyżaniak et al. [40], these clones contained approx. $75 \%$ polysaccharides. In turn, Stolarski et al. [41] determined the content of polysaccharide substances in the wood of 2- and 3-year Salix clones (Corda, Tur, Turbo, Duotur) at $67-70 \%$. Woody bamboo stems were found to contain approx. $71 \%$ holocellulose [42]. The above analysis shows that plant biomass harvested over a short cycle exhibits similar polysaccharide contents, which may affect the heat of combustion. However, confirmation of this assumption will require additional research.

Hemicelluloses, i.e., carbohydrates with a low degree of polymerization, in plants play the role of the skeleton substance (pentosans) and nutrients (hexosans). They amount to approx. $20-30 \%$ in the xylem [32]. Similar levels of hemicellulose were reported by Stolarski et al. [41] in the wood of Salix clones harvested in a 1-year cycle (they found from $26.56 \%$ to $31.89 \%$ of these substances). In turn, Gismatulina and Budaeva [23] recorded from $20.0 \%$ to $25.3 \%$ pentosans alone in biomass from Miscanthus, whereas Doczekalska et al. [36] showed the hemicellulose content of various Miscanthus species to be approx. $29 \%$, and that of switchgrass to be $30.5 \%$. These values are comparable to those obtained in this study. In the investigated grass species, the hemicellulose content ranged from $30.27 \%$ to $34.31 \%$ (in sweet vernal grass). Slightly lower contents of hemicellulose were reported by Ansah et al. [38] in Napier grass varieties, which contained from $19.55 \%$ to $25.23 \%$ carbohydrates with a low degree of polymerization. When investigating several grass species to be used 
in the production of biogas, Dandikas et al. [22] found approx. $27 \%$ hemicellulose. The level of hemicellulose in those grasses was more than twice as high as in bamboo wood, where it is as low as 14\% [42]. The investigated grass species contained large amounts of hemicellulose compared with various other sources of plant biomass, which may encourage the utilization of these grass species in the production of biogas [43,44].

Extractives in wood account for a very low percentage of dry matter, as little as $2-6 \%$, and their level depends on the species, the part of the plant and the extraction mixture [32]. Grasses contain much greater amounts of these compounds. In this study, the level of substances soluble in ethanol ranged from $9.72 \%$ to $18.26 \%$. These amounts showed the greatest variability among the chemical components of biomass. Murawski et al. [39] reported similar contents of extractives in sedge grasses, from $9.7 \%$ to $17.7 \%$. Waliszewska et al. [37] found 8.1-8.3\% extractives in Carex riparia and C. paniculata, and $13.6 \%$ to $23.1 \%$ in seven other Carex species. A mixture of ethanol and benzene is a very good solvent of waxes, fats, resins and tannins, among others. Chen et al. [42], when using this solvent in the analysis of bamboo wood, recorded the content of these substances at approximately 9.5\%. According to Doczekalska et al. [36], grasses from the genus Miscanthus contained from $2.54 \%$ to $2.97 \%$ extractives depending on the species, while in switchgrass, the content was 3.14\%. In Miscanthus, slightly higher amounts (2.8-5.7\%) of these compounds, depending on the age of the plants, were reported by Gismatulina and Budaeva [23]. The analysis of literature data shows that grasses are characterized by relatively high amounts of compounds soluble in organic solvents, and their levels fall within a wide range of values. Grasses may be a source of many valuable active substances. Gismatulina and Budaeva identified as many as 24 fatty acids in extracts from Miscanthus.

It is essential to know the ash contents of fuels used for energy generation purposes. The mean ash content in non-woody solid fuels ranges from $4 \%$ to $7 \%$. The investigated grass species contained from $5.04 \%$ to $8.27 \%$ mineral compounds, except for sweet vernal grass, which contained $3.26 \%$ ash. Generally, grasses and cereal straw contain greater amounts of mineral substances than wood, which, depending on the species, plant part and felling date, contains from $0.2 \%$ to $1.0 \%$ of these compounds [32]. However, this may not be necessarily a disadvantage of plant biomass, since ash-due to its contents of micro- and macroelements-may be used as a fertilizer [45]. Kalembasa [46] recorded the content of macronutrients at $91.9 \%$ in ash from Miscanthus, including calcium at $38.6 \%$ and potassium at $33.0 \%$, while the content of microelements was $4.87 \%$, thus showing the potential for soil enrichment using this ash. Maiden silvergrass (Miscanthus sinensis) contained $5.25 \%$ ash, Virginia fanpetals (Sida hermaphrodita) 5.95\% and osier (Salix sp.) 3.15\% [46]. The contents of minerals in plants are also affected by growth conditions. Gismatulina and Budaeva [23] recorded relatively high amounts of minerals in the Miscanthus var. Soranovskii genotype growing in the severe continental climate of Siberia, ranging from $3.57 \%$ to $6.30 \%$. Similar levels of ash in Miscanthus sinensis (5.25\%) and Sida hermaphrodita $(5.95 \%)$ were reported by Kalembasa [46]. These levels were comparable to the ash contents in the grasses investigated in this study. Doczekalska et al. [36] recorded much lower amounts of mineral compounds in Miscanthus giganteus, M. sacchariflorus and $M$. sinensis coming from experimental plantations in Poznań, amounting to 2.63\%, 2.16\% and 2.54\%, respectively, while the content in switchgrass was $2.20 \%$. Aboveground parts of grasses from the genus Carex harvested in a 1-year cycle contained from $4.2 \%$ to $7.3 \%$ minerals, except for C. riparia, which had as much as $12.3 \%$ ash [37]. Murawski et al. [39] recorded 6.5-7.1\% mineral substances in grasses harvested from extensively managed meadows. These amounts of ash were comparable to those found in this study in annual grasses. A slightly higher than average ash content $(8.1 \%)$ in the Carex praecox community was also reported by Grzelak et al. [47]. Various genotypes of Napier grass contained from $6.0 \%$ to $6.9 \%$ ash [38]. Kowalczyk-Juśko [48], when investigating the contents of mineral substances and their composition in Miscanthus sacchariflorus, Spartina pectinata, Sida hermaphrodita, Helianthus tuberosus and Rosa multiflora, recorded 3.70\%, 4.10\%, 2.80\%, 5.60\% and 3.10\% contents of these compounds, respectively. Among other crops grown for energy generation 
purposes and harvested in a 1-year cycle, Silphium perfoliatum contains approx. 3.4\% ash [49], while in Helianthus tuberosus, ash contents range from $2.52 \%$ [50] to 5.60\% [51], Spartina pectinata L. contains 4.9-5.4\% ash [52] and Agropyron elongatum Host. has 3.2\% ash [53]. The levels of ash in these plants are comparable to or slightly lower than those in the grasses investigated in this study. The presented literature data indicate that the amount of ash in grasses does not differ from that in annual plants grown and used for energy generation purposes, while slightly higher contents of ash may even be advantageous in view of the potential for use in soil fertilization. Studied grasses come from extensively managed meadows, and they are not polluted areas, but semi-natural grassy communities. However, to ensure low contents of hazardous elements, their contents will be determined in ash.

The determined heat of combustion for the grasses fell within a range of $17.500-18.800 \mathrm{MJ} / \mathrm{kg}$. Only wood small-reed and common couch had values exceeding $19.000 \mathrm{MJ} / \mathrm{kg}$. Compared with the heat of combustion of wood from willow species grown for energy generation purposes, amounting to approx. 19.350 [54] and $19.500 \mathrm{MJ} / \mathrm{kg}$ [40], these values were slightly lower, while in the case of wood small-reed and common couch, they were comparable. The fact that the ash contents of grasses exceed that of willow wood does not cause a significant reduction in the heat of combustion in the studied grasses. Slightly higher values of the heat of combustion than those found in this study were reported for Carex grasses by Waliszewska et al. [37]. For most of these grasses, the heat of combustion ranged from 19.000 to $19.750 \mathrm{MJ} / \mathrm{kg}$; only Carex riparia, which has a high ash content (12.3\%), had a lower heat of combustion (17.790 MJ/kg). Additionally, Murawski et al. [39] gave almost identical values of the heat of combustion, from 17.1 to $19.4 \mathrm{MJ} / \mathrm{kg}$, for grasses from extensively managed meadows. High values of the heat of combustion (from 19.000 to $19.450 \mathrm{MJ} / \mathrm{kg}$ ) for grasses from meadows in the Noteć valley were reported by Grzelak et al. [47], with only Caricetum ripariae producing a lower value $(17.790 \mathrm{MJ} / \mathrm{kg})$. The values of the heat of combustion obtained for grasses in this study are sufficiently high for them to be considered as sources of biomass for combustion for energy generation purposes.

The heating value is the amount of heat obtained at complete combustion of a unit of fuel at a constant volume. This is lower than the heat of combustion by the heat of condensation of the water vapor contained in the combustion gases. For the investigated grass species, this value ranged from 16.029 to $17.793 \mathrm{MJ} / \mathrm{kg}$, except in the case of wood small-reed, where it exceeded $18.000 \mathrm{MJ} / \mathrm{kg}$. Grasses from the Noteć valley were found to have similar heating values, ranging from 16.040 to $17.930 \mathrm{MJ} / \mathrm{kg}$ dry matter [47]. It should be noted that for laboratory tests, the grasses were dried in a climatic room, and their humidity was low. Grass naturally dried in a meadow may have higher humidity. Consequently, the calorific value may be lower. According to Murawski et al. [39], heating values for grasses from extensively managed meadows range from 16.1 to $18.1 \mathrm{MJ} / \mathrm{kg}$ d.m., while for sedges, they range from 16.0 to $18.7 \mathrm{MJ} / \mathrm{kg}$. Almost identical heating values for sedges, from 16.040 to $18.010 \mathrm{MJ} / \mathrm{kg}$, were given by Waliszewska et al. [37]. These are very similar to the values obtained in this study. Plants grown for energy generation purposes and harvested in a 1-year cycle include, for instance, Virginia fanpetal and various Miscanthus varieties. Mirowski et al. [55] reported the heating value for Virginia fanpetal at $14.5-16.1 \mathrm{MJ} / \mathrm{kg}$, and that for Miscanthus at 11.1-16.1 MJ/kg. According to Kołodziej and Matyka [56], the heating value of Virginia fanpetal biomass is $17.3 \mathrm{MJ} / \mathrm{kg}$, while for Miscanthus, it is $17.4 \mathrm{MJ} / \mathrm{kg}$. Heating values of various types of cereal straw (rye, wheat, triticale, barley, maize, rape and flax) are reported at 17.1-17.8 MJ/kg [55]; the same study determined the heating value of meadow grass at $16.5 \mathrm{MJ} / \mathrm{kg}$ and that of reed at $16.4 \mathrm{MJ} / \mathrm{kg}$. According to Kowalczyk-Juśko [57], the heating value of dry matter biomass in prairie cordgrass was $17.24-17.84 \mathrm{MJ} / \mathrm{kg}$ depending on the vegetation year. The results of Mirowski et al. [55], Kowalczyk-Juśko [57], Waliszewska et al. [37] and the abovementioned authors are all very similar to those obtained for the grasses investigated in this study. The mean heating value of dry ash-free matter for monocotyledonous plants (grasses, 
cereal straw and reeds) according to the Technical Specifications (CEN/TS 14961:2007) is $18.4-18.5 \mathrm{MJ} / \mathrm{kg}$. Based on this information, it may be stated that the results obtained in this study show the investigated grass species to have slightly lower than average heating values for plant biomass. In turn, biomass derived from the aboveground parts of the studied grass species may be a good renewable raw material for energy generation.

\section{Conclusions}

1. According to the hypothesis, Polish grasses from ecological sites are suitable for bioenergy conversion.

2. The contents of cellulose, lignin and holocellulose do not differ from those in other annual plants. High contents of cellulose in reed canary grass and common bent indicate the potential for conversion of these species to produce cellulose as a valuable raw material.

3. The above-average content of polysaccharides with a low degree of polymerization indicates the potential use of such plant biomass in biogas production. In this respect, three species seem to be of particular interest: Bromus inermis, Calamagrostis epigejos and Anthoxanthum odoratum.

4. The studied grass species had high contents of extractives, which suggests that they may be sources of valuable active substances for use as dietary supplements or in cosmetics. The analyses show that the best species in this respect would be Agropyron repens, Bromus inermis and Arrhenatherum elatius.

5. No correlation was found between contents of individual chemical components and the heat of combustion of the investigated grasses (data not shown). Neither the content of cellulose, nor that of lignin showed a definite effect on the heating value or heat of combustion. The best suited for use in energy generation are the species whose heating value exceeded $17.000 \mathrm{MJ} / \mathrm{kg}$. These were Phalaris arundinacea, Calamagrostis epigejos, Phragmites australis, Agropyron repens and Bromus inermis.

6. The higher contents of ash characteristics for grasses do not reduce the energy properties of these plants, while ash may additionally be used in soil fertilization. Among the investigated grass species, the most favorable in this respect were Agropyron repens, Bromus inermis and Arrhenatherum elatius.

Author Contributions: Conceptualization, B.W. and M.G.; methodology, B.W. and M.G.; software, W.C.; validation, B.W., M.G. and W.C.; formal analysis, B.W., A.S.-D. and A.S.; investigation, B.W. and M.G.; resources, E.G.; data curation, B.W. and M.G; writing-original draft preparation, B.W., M.G., E.G. and W.C.; writing-review and editing, W.C.; visualization, M.G. and W.C.; supervision, B.W. and M.G.; project administration, M.G. and E.G.; funding acquisition, M.G. and B.W. All authors have read and agreed to the published version of the manuscript.

Funding: The publication was co-financed within the framework of the Ministry of Science and Higher Education program "Regional Initiative Excellence" in the years 2019-2022, project no. 005/RID/2018/19.

Institutional Review Board Statement: Not applicable.

Informed Consent Statement: Not applicable.

Data Availability Statement: Not applicable.

Conflicts of Interest: The authors declare no conflict of interest. 


\section{References}

1. EEA. National Monitoring, Reporting and Evaluation of Climate Change Adaptation in Europe; EEA Technical Report No 20/2015; European Environment Agency: København, Denmark, 2015; Available online: https://www.eea.europa.eu/publications/ national-monitoring-reporting-and-evaluation (accessed on 1 November 2020).

2. Czekała, W.; Bartnikowska, S.; Dach, J.; Janczak, D.; Smurzyńska, A.; Kozłowski, K.; Bugała, A.; Lewicki, A.; Cieślik, M.; Typańska, D.; et al. The energy value and economic efficiency of solid biofuels produced from digestate and sawdust. Energy 2018, 159, 1118-1122. [CrossRef]

3. Cieślik, M.; Dach, J.; Lewicki, A.; Smurzyńska, A.; Janczak, D.; Pawlicka-Kaczorowska, J.; Boniecki, P.; Cyplik, P.; Czekała, W.; Jóźwiakowski, K. Methane fermentation of the maize straw silage under meso- and thermophilic conditions. Energy 2016, 115, 1495-1502. [CrossRef]

4. Mazurkiewicz, J.; Marczuk, A.; Pochwatka, P.; Kujawa, S. Maize Straw as a Valuable Energetic Material for Biogas Plant Feeding. Materials 2019, 12, 3848. [CrossRef] [PubMed]

5. Kowalczyk-Juśko, A.; Kościk, B.; Jóźwiakowski, K.; Marczuk, A.; Zarajczyk, J.; Kowalczuk, J.; Szmigielski, M.; Sagan, A. Effects of biochemical and thermochemical conversion of sorghum biomass to usable energy/Efekty biochemicznej i termochemicznej konwersji biomasy sorga (Sorghum bicolor Moench.) na energię użytkowa. Przem. Chem. 2015, 1, 212-214. [CrossRef]

6. Pochwatka, P.; Kowalczyk-Jusko, A.; Mazur, A.; Janczak, D.; Pulka, J.; Dach, J.; Mazurkiewicz, J. Energetic and Economic Aspects of Biogas Plants Feed with Agriculture Biomass. In Proceedings of the 2020 4th International Conference on Green Energy and Applications, ICGEA 2020, Singapore, 7-9 March 2020; Institute of Electrical and Electronics Engineers Inc.: Piscataway, NJ, USA, 2020; pp. 130-133.

7. Wannasek, L.; Ortner, M.; Amon, B.; Amon, T. Sorghum, a sustainable feedstock for biogas production? Impact of climate, variety and harvesting time on maturity and biomass yield. Biomass Bioenergy 2017, 106, 137-145. [CrossRef]

8. Kowalczyk-Juśko, A.; Pochwatka, P.; Zaborowicz, M.; Czekała, W.; Mazurkiewicz, J.; Mazur, A.; Janczak, D.; Marczuk, A.; Dach, J. Energy value estimation of silages for substrate in biogas plants using an artificial neural network. Energy 2020, 202. [CrossRef]

9. Perzon, M. Emissions of organic compounds from the combustion of oats-A comparison with softwood pellets. Biomass Bioenergy 2010, 34, 828-837. [CrossRef]

10. Czekała, W.; Dach, J.; Janczak, D.; Smurzyńska, A.; Kwiatkowska, A.; Kozłowski, K. Influence of maize straw content with sewage sludge on composting process. J. Water Land Dev. 2016, 30, 43-49. [CrossRef]

11. Janczak, D.; Malińska, K.; Czekała, W.; Cáceres, R.; Lewicki, A.; Dach, J. Biochar to reduce ammonia emissions in gaseous and liquid phase during composting of poultry manure with wheat straw. Waste Manag. 2017, 66, 36-45. [CrossRef] [PubMed]

12. Waszkielis, K.M.; Wronowski, R.; Chlebus, W.; Białobrzewski, I.; Dach, J.; Pilarski, K.; Janczak, D. The effect of temperature, composition and phase of the composting process on the thermal conductivity of the substrate. Ecol. Eng. 2013, 61, 354-357. [CrossRef]

13. Białobrzewski, I.; Mikš-Krajnik, M.; Dach, J.; Markowski, M.; Czekała, W.; Głuchowska, K. Model of the sewage sludge-straw composting process integrating different heat generation capacities of mesophilic and thermophilic microorganisms. Waste Manag. 2015, 43, 72-83. [CrossRef] [PubMed]

14. Pochwatka, P.; Kowalczyk-Juśko, A.; Sołowiej, P.; Wawrzyniak, A.; Dach, J. Biogas Plant Exploitation in a Middle-Sized Dairy Farm in Poland: Energetic and Economic Aspects. Energies 2020, 13, 6058. [CrossRef]

15. Kohli, K.; Prajapati, R.; Sharma, B.K. Bio-Based Chemicals from Renewable Biomass for Integrated Biorefineries. Energies 2019, 12, 233. [CrossRef]

16. GUS. Rocznik Statystyczny Rolnictwa; Główny Urząd Statystyczny: Warszawa, Poland, 2016. (In Polish)

17. Dubert, F.; Górski, F. Cultivation of "Energy Plants"—Benefits and Dangers; Annual Report 2010; Polish Academy of Sciences: Warszawa, Poland, 2010; pp. 69-73.

18. Cintas, O.; Berndes, G.; Cowie, A.L.; Egnell, G.; Holmström, H.; Marland, G.; Ågren, G.I. Carbon balances of bioenergy systems using biomass from forests managed with long rotations: Bridging the gap between stand and landscape assessments. GCB Bioenergy 2017, 9, 1238-1251. [CrossRef]

19. Ahorsu, R.; Medina, F.; Constantí, M. Significance and Challenges of Biomass as a Suitable Feedstock for Bioenergy and Biochemical Production: A Review. Energies 2018, 11, 3366. [CrossRef]

20. Stolarski, M.J.; Warmiński, K.; Krzyżaniak, M. Energy Value of Yield and Biomass Quality of Poplar Grown in Two Consecutive 4-Year Harvest Rotations in the North-East of Poland. Energies 2020, 13, 1495. [CrossRef]

21. Wicke, B.; Kluts, I.; Lesschen, J.P. Bioenergy Potential and Greenhouse Gas Emissions from Intensifying European Temporary Grasslands. Land 2020, 9, 457. [CrossRef]

22. Dandikas, V.; Heuwinkel, H.; Lichti, F.; Drewes, J.E.; Koch, K. Correlation between Biogas Yield and Chemical Composition of Grassland Plant Species. Energy Fuels 2015, 29, 7221-7229. [CrossRef]

23. Gismatulina, Y.A.; Budaeva, V.V. Chemical composition of five Miscanthus sinensis harvests and nitric-acid cellulose therefrom. Ind. Crop. Prod. 2017, 109, 227-232. [CrossRef]

24. TAPPI. T $204 \mathrm{~cm}-07$-Solvent Extractives of Wood and Pulp; Standards Technical Association of the Pulp and Paper Industry: Atlanta, GA, USA, 2007. 
25. Seifert, K. Zur Frage der Cellulose-Schnellbestimmung nach der Acetylaceton-Methode. Das Pap. 1960, 14, 104-106. (In German)

26. TAPPI. T-222 om-06 - Lignin in Wood and Pulp; Standards Technical Association of the Pulp and Paper Industry: Atlanta, GA, USA, 2006.

27. TAPPI. T 9 wd-75-Holocellulose in Wood; Standards Technical Association of the Pulp and Paper Industry: Atlanta, GA, USA, 1975.

28. DIN. DIN 51731. Testing of Solid Fuels_Compressed Untreated Wood-Requirements and Testing; Deutsches Institut für Normung E.V. (German National Standard): Berlin, Germany, 1996.

29. ISO. PN-EN ISO 16948: 2015-07 Solid Biofuels. Total Carbon, Hydrogen and Nitrogen Determination; ISO: Geneva, Switzerland, 2015.

30. Kupryaniuk, K.; Oniszczuk, T.; Combrzyński, M.; Dach, J.; Czekała, W. Process Efficiency and Energy Consumption during the Extrusion of Lignocellulosic Materials. Proc. IOP Conf. Ser. Earth Environ. Sci. 2020, 505, 012040. [CrossRef]

31. Gizińska-Górna, M.; Czekała, W.; Jóźwiakowski, K.; Lewicki, A.; Dach, J.; Marzec, M.; Pytka, A.; Janczak, D.; Kowalczyk-Juśko, A.; Listosz, A. The possibility of using plants from hybrid constructed wetland wastewater treatment plant for energy purposes. Ecol. Eng. 2016, 95, 534-541. [CrossRef]

32. Prosiński, S. Chemia Drewna (Wood Chemistry); PWRiL: Warszawa, Poland, 1984. (In Polish)

33. Rowell, R.M.; Han, J.S.; Bisen, S.S. Changes in fiber properties during the growing season. In Paper and Composite from Agro-Based Resources; Rowell, R.M., Young, R.A., Rowell, J.K., Eds.; Lewis Publishers: Boca Raton, FL, USA; New York, NY, USA; London, UK; Tokyo, Japan, 1997; pp. 23-37.

34. Baeza, J.; Freer, J. Chemical Characterization of Wood and Its Components. In Wood and Cellulosic Chemistry, 2nd ed.; Hon, N.-S., Shiraishi, N., Eds.; Marcel Dekker Inc.: New York, NY, USA, 2001; p. 275.

35. Waliszewska, B.; Prądzyński, W. Basic chemical analysis and polymerization level of cellulose in the year-old and the multiyear shrubby willows growing by the A-2 motorway. Proceedings of National Symposium, Biological Reactions of Trees to Industrial Pollution, Kórnik, Poland, 29 May-1 June 2001; pp. 725-732.

36. Doczekalska, B.; Bartkowiak, M.; Waliszewska, B.; Orszulak, G.; Cerazy-Waliszewska, J.; Pniewski, T. Characterization of Chemically Activated Carbons Prepared from Miscanthus and Switchgrass Biomass. Materials 2020, 13, 1654. [CrossRef] [PubMed]

37. Waliszewska, B.; Janyszek, M.; Grzelak, M.; Gawel, E. Characteristic of thermochemical parameters of aboveground parts of selected sedges (Carex L Cyperaceae). IOSR J. Agric. Vet. Sci. 2013, 5, 1-6. [CrossRef]

38. Ansah, T.; Osafo, E.; Hansen, H. Herbage yield and chemical composition of four varieties of Napier (Pennisetum purpureum) grass harvested at three different days after planting. Agric. Biol. J. N. Am. 2010, 1, 923-929. [CrossRef]

39. Murawski, M.; Grzelak, M.; Waliszewska, B.; Knioła, A.; Czekała, W. Energy value and yielding from extensively used meadows. Fragm. Agron. 2015, 32, 71-78.

40. Krzyżaniak, M.; Stolarski, M.J.; Waliszewska, B.; Szczukowski, S.; Tworkowski, J.; Załuski, D.; Śnieg, M. Willow biomass as feedstock for an integrated multi-product biorefinery. Ind. Crop. Prod. 2014, 58, 230-237. [CrossRef]

41. Stolarski, M.J.; Szczukowski, S.; Tworkowski, J.; Wróblewska, H.; Krzyżaniak, M. Short rotation willow coppice biomass as an industrial and energy feedstock. Ind. Crop. Prod. 2011, 33, 217-223. [CrossRef]

42. Chen, Q.; Endo, T.; Wang, Q. Characterization of bamboo after ionic liquid- $\mathrm{H}_{2} \mathrm{O}$ pretreatment for the pyrolysis process. Bioresources 2015, 10, 2797-2808. [CrossRef]

43. Bedoić, R.; Čuček, L.; Ćosić, B.; Krajnc, D.; Smoljanić, G.; Kravanja, Z.; Ljubas, D.; Pukšec, T.; Duić, N. Green biomass to biogas-A study on anaerobic digestion of residue grass. J. Clean. Prod. 2019, 213, 700-709. [CrossRef]

44. Antonopoulou, G.; Vayenas, D.; Lyberatos, G. Biogas Production from Physicochemically Pretreated Grass Lawn Waste: Comparison of Different Process Schemes. Molecules 2020, 25, 296. [CrossRef]

45. Piekarczyk, M.; Kotwica, K.; Jaskulski, D. The elemental composition of ash from straw and hay in the context of their agricultural utilization. Acta Sci. Pol. Agric. 2011, 10, 97-104.

46. Kalembasa, D. The amount and chemical composition of ash obtained from biomass of energy crops. Acta Agrophys. 2006, 7, 909-914.

47. Grzelak, M.; Gaweł, E.; Waliszewska, B.; Janyszek, M.; Wrońska-Pilarek, D.; Murawski, M.; Knioła, A. Floristic and habitat variability, nature and energy value of selected sedge communities. Steciana 2017, 20, 233-238. [CrossRef]

48. Kowalczyk-Juśko, A. Popiół z różnych roślin energetycznych (Ash from different energy crops). Proc. ECOpole 2009, 3, 159-164. (In Polish)

49. Frączek, J.; Mudryk, K.; Wróbel, M. Rożnik przerośnięty Silphium perfoliatum L.—Źródło biomasy do produkcji biopaliw stałych (Cup plant Silphium perfoliatum L.-A source of biomass for the production of solid biofuels). Inż. Rol. 2011, 6, 21-27. (In Polish)

50. Komorowicz, M.; Wróblewska, H.; Pawłowski, J. Skład chemiczny i właściwości energetyczne biomasy z wybranych surowców odnawialnych (Chemical composition and heating value of biomass from selected renewable raw materials). Ochr. Środ. Zasobów Nat. 2009, 40, 402-410. (In Polish)

51. Kowalczyk-Juśko, A. The influence of the ash from the biomass on the power boiler pollution. J. Ecol. Eng. 2017, 18, 200-204. [CrossRef]

52. Kowalczyk-Juśko, A.; Kościk, B. Produkcja biomasy miskanta cukrowego i spartiny preriowej w zróżnicowanych warunkach glebowych oraz możliwości jej konwersji na energię (Production of biomass from Amur silvergrass and prairie cordgrass under various soil conditions and potential conversion of such biomass to energy). Biul. IHAR 2004, 234, $213-218$.

53. Martyniak, D. Perz wydłużony—Nowa roślina na cele energetyczne (Tall wheatgrass—A new energy crop). Agro Serwis 2009, 18, 76-77. 
54. Stolarski, M.; Mleczek, M.; Szczukowski, S.; Goliński, P.; Waliszewska, B.; Szentner, K.; Rutkowski, P.; Krzyżaniak, M. Characteristics of Thermophysical Parameters of Selected Salix Taxa with Elemental Analysis. Int. J. Green Energy 2015, 12, 1272-1279. [CrossRef]

55. Mirowski, T.; Mokrzycki, E.; Uliasz-Bocheńczyk, A. Energetyczne Wykorzystanie Biomasy (Utilisation of Biomass for Energy Generation); Wydawnictwo IGSMiE PAN: Kraków, Poland, 2018. (In Polish)

56. Kołodziej, B.; Matyka, M. Odnawialne Źródła Energii. Rolnicze Surowce Energetyczne (Renewable Energy Sources. Agricultural Energy Resources); PWRiL: Warszawa, Poland, 2012. (In Polish)

57. Kowalczyk-Juśko, A. Biometric and energetic parameters of cordgrass (Spartina pectinata L.) in the first three years of growth. Probl. Agric. Eng. 2010, 2, 69-77. 